\title{
Quality characteristics of dumpling shell with sea tangle powder
}

\author{
In-Duck Park* \\ Department of Culinary Art, Chodang University, Muan 534-701, Korea
}

\section{다시마 분말을 첨가한 만두피의 품질 특성}

\author{
박인덕* \\ 초당대학교 조리과학부
}

\begin{abstract}
This study investigated the effects of sea tangle powder (SP) on the physicochemical and sensory characteristics of dumpling shells. Various dumpling shell samples were prepared with wheat flour containing different amounts of SP. The characteristics of the dumpling shell samples were investigated based on their viscosity, cooking properties, color values, and texture properties. Their sensory characteristics were evaluated by using seven scores. According to the amylograph data, the composite SP-wheat flour samples showed an increased gelatinization temperature with an increasing SP content, whereas the initial viscosity at $95^{\circ} \mathrm{C}$ was decreased after 15 minutes. The increase of $S P$ amount decreased the values of $L$ and $b$ whereas the a value increased. With regard to the textural characteristics, the dumpling shells with an increased amount of SP showed increased hardness, cohesiveness, and adhesiveness, whereas the SP addition reduced the springiness of the dumpling shell. The dumpling shell with the addition of $3 \%$ SP showed the highest overall acceptability in the sensory evaluation.
\end{abstract}

Key words : sea tangle powder, dumpling shell, quality characteristics

\section{서 론}

다시마(Laminaria longissima)는 갈조식물군 중 다시마과 에 속하며, 동의보감에서는 '곤포'라 하여 신체의 저항성을 높여주고, 노폐물의 배설을 촉진하며, 고혈압, 동맥경화, 갑산선종, 신장염에 효과가 있을 뿐 아니라 암세포의 증식 을 억제하고, 노화를 예방하는 건강장수식품이라고 기록하 고 있다(1). 다시마는 칼륨, 나트륨, 칼슘, 마그네슘 등 신체 의 생리 대사에 관여하는 무기질을 다량 함유하며 갑상선 호르몬의 주성분인 요오드를 4,000 ppm 이상 함유하고 있 을 뿐 아니라 식이섬유인 알긴산을 풍부하게 함유하고 있 다. 알긴산은 동맥경화 및 대장암을 예방하고, 비만 억제 및 면역력 증강 등의 생리활성 기능이 알려져 있으며(2-5),

*Corresponding author. E-mail : idpark@cdu.ac.kr

Phone : 82-61-450-1644 Fax : 82-61-450-1641

Received 1 December 2014; Revised 15 January 2015; Accepted 24 February 2015.

Copyright (c) The Korean Society of Food Preservation. All rights reserved.
다양한 기능성 소재나 건강식품으로 많이 이용되고 있다 $(6,7)$. 다시마 중에 함유된 저분자 질소화합물 중 하나인 laminine은 혈압 강하 작용을 하는 것으로 밝혀져 있으며, 산성 다당류인 fucoidan이 풍부하게 함유되어 있어 항혈액 응고작용과 항암효과 등 다양한 생리기능을 하는 것으로 알려져 있다(8). 최근 다시마의 항종양성, 항바이러스성, 항돌연변이 및 항산화 효과 등의 생리적 기능(9-11)이 구체 적으로 확인됨으로써 다시마의 수요는 점차 증가하고 있 다. 국내에서 보고된 다시마의 다양한 식품소재 이용에 관 한 연구로는 다시마 첨가 김치(12), 다시마 추출물 요구르트 (13), 다시마, 미역 및 멸치분말이 첨가된 된장의 품질(14), 다시마 분말이 당뇨 유발 쥐의 혈당과 지질농도 및 항산화 효소계에 미치는 영향(15), 다시마 첨가 식빵 및 설기떡의 품질특성 $(7,16)$, 다시마 쿠키의 항산화효과(1), 다시마 매작 과의 산화안정성(11), 다시마 머핀의 품질특성(17), 해양심 층수 및 다시마가루를 첨가하여 제조한 간장의 생리활성 효과(18), 다시마 발아현미 쿠키의 제조조건의 최적화(19) 등 활발한 연구가 진행되고 있다.

만두는 우리나라 주식류의 한 종류로 하루 세끼의 식사 
중 주로 점심이나 저녁에 식사대용으로 먹기도 하지만 간식 으로 혹은 별식으로 남녀노소를 구분하지 않고 즐겨 이용되 고 있는 음식이다. 또한 한국인의 식습관에 가장 적합한 특징으로 원료 및 형태에 따라 다양한 제품의 구현이 가능 하기 때문에 향후 지속적인 성장이 가능한 품목군으로 평가 되고 있다(20). 냉동식품으로 많이 이용되고 있는 만두는 가정에서 간편 영양식으로 선호하며, 단체급식에서도 자주 제공되는 음식 중의 하나로 소비자들의 다양한 요구에 맞는 만두피의 개발이 지속적으로 필요하다. 만두피에 관한 연 구로는 울금(20), 콩가루(21), 쌀가루(22), 홍어(23), 새우 (24), 파래(25), 새송이(26), 비파잎(27), 고아미(28) 분말 등 을 첨가한 만두피의 품질특성연구가 이루어졌을 뿐이다. 따라서 본 연구에서는 다시마 분말을 이용한 가공제품의 개발 및 다시마 활용도를 높이고, 다양한 만두피 개발을 위해 다시마 분말을 첨가한 만두피를 제조하여 품질특성을 조사함으로써 다시마 만두피 제품개발을 위한 기초자료로 삼고자 하였다.

\section{재료 및 방법}

\section{재 료}

본 실험에 사용된 다시마 분말은 2011년 생산된 건조품 (해마루 마을, 전남 완도군)을 구입하여 시료로 사용하였다. 밀가루는 제면용(중력분, (주)대한제분, 양산시, 한국)을 구 입하여 사용하였고, 소금은 천일염(신안토판염, 신안군, 한 국)을 사용하였다.

\section{만두피의 제조}

실험에 사용된 만두피의 다시마 분말 함유량은 예비실험 을 거쳐 관능적 특성을 고려하여 총 가루분량의 $1 \%, 3 \%$, $5 \%$ 및 $7 \%$ 로 결정하였다. 만두피 반죽은 밀가루 $100 \mathrm{~g}$ 에 소금 $2 \mathrm{~g}$, 물 $40 \mathrm{~g}$ 을 넣어 반죽 한 후 상온에서 30 분간 숙성시킨 뒤 가정용 국수제조기(Aryuk Industrial Inc., Seoul, Korea)를 사용하여 두께 $1.00 \mathrm{~mm}$, 직경 $7 \mathrm{~cm}$ 의 원형 만두피를 제조하였다. 다시마 분말의 첨가량을 달리하여 제조한 만두피의 배합비는 Table 1 과 같다.

\section{아밀로그래프에 의한 점도 특성}

Amylograph에 의한 시료의 호화양상 측정은 Brabender Micro Visco-Amylograph(Brabender Co., Duisburg, Germany) 를 사용하여 Park과 Cho(24)의 방법에 따라 측정하였다. 시료 $65 \mathrm{~g}(14 \% \mathrm{mb}$.$) 에 증류수 450 \mathrm{~mL}$ 를 가한 현탁액을 amylograph 호화 용기에 넣고, $30^{\circ} \mathrm{C}$ 에서 $95^{\circ} \mathrm{C}$ 까지 $1.5^{\circ} \mathrm{C} / \mathrm{min}$ 로 호화시킨 후 $95^{\circ} \mathrm{C}$ 에서 15 분간 유지시켜 호화개시온도, 최고점도, $95^{\circ} \mathrm{C}$ 에서의 점도, $95^{\circ} \mathrm{C}$ 에서 15 분 후의 점도 등을 측정하였다.
Table 1. Formula for the dumpling shell with varied amounts of sea tangle powder added

\begin{tabular}{lccccc}
\hline \multirow{2}{*}{ Ingredient (g) } & \multicolumn{5}{c}{ Sample $^{1)}$} \\
\cline { 2 - 6 } & Control & SP-1\% & SP-3\% & SP-5\% & SP-7\% \\
\hline Flour & 100 & 99 & 97 & 95 & 93 \\
Sea tangle powder & 0 & 1 & 3 & 5 & 7 \\
Salt & 2 & 2 & 2 & 2 & 2 \\
Water & 40 & 40 & 40 & 40 & 40 \\
\hline
\end{tabular}

${ }^{1)}$ Control, no sea tangle powder; SP- $1 \%, 1 \%$ sea tangle powder added; SP-3\%, $3 \%$ sea tangle powder added; SP-5\%, $5 \%$ sea tangle powder added; SP-7\%, $7 \%$ sea tangle powder added.

\section{만두피의 조리특성}

만두피의 조리 시 변화는 Kim 등(24)의 방법으로 분석하 였다. 만두피 $50 \mathrm{~g}$ 을 끓는 물 $400 \mathrm{~mL}$ 에 넣고 3 분간 삶은 후 30 초간 냉수에서 냉각시켜 3 분간 물을 뺀 뒤 만두피의 무게를 측정하고, 조리 전후의 무게 차이로 중량변화를 측 정하였다. 만두피의 수분 흡수율은 조리 후 만두피의 중량 에서 생 만두피의 중량을 빼고 다시 생 만두피의 중량으로 나눈 후 100 을 곱하여 계산하였다. 삶은 만두피의 부피는 $500 \mathrm{~mL}$ 메스실린더에 $300 \mathrm{~mL}$ 의 물을 채운 다음, 수분흡수 율을 측정한 만두피를 메스실린더에 넣어 증가하는 물의 부피를 측정하여 구하였다. 만두피 국물의 탁도는 고형물 의 용출 정도를 나타내는 수치로서 조리를 끝낸 국물을 2 배로 희석하여 실온에서 냉각한 후 분광광도계(UV1601PC, Shimadzu Co., Tokyo, Japan)를 사용하여 $675 \mathrm{~nm}$ 에 서 흡광도를 측정하였다. 모든 실험은 3 회 반복하여 실시하 여 그 결과는 평균값으로 나타내었다.

\section{만두피의 색도}

만두피의 색도는 만두피를 끓는 물에 넣고 3 분간 삶은 후 물을 뺀 뒤 측정용기에 담아서 색차계(CR-200, Minolta, Tokyo, Japan)를 이용하여 밝기(L, lightness), 적색도(a, redness), 황색도(b, yellowness) 값을 5 회 반복 측정하고 그 평균값으로 나타내었다. 여기에 사용한 표준백색판 (standard plate)의 $\mathrm{L}, \mathrm{a}, \mathrm{b}$ 값은 $91.3,1.4,4.5$ 이었다.

만두피의 조직감

만두피의 조직감 특성은 두께 $1.00 \mathrm{~mm}$, 직경 $7 \mathrm{~cm}$ 의 원형 만두피를 끓는 물에서 삶은 후 물기를 뺀 뒤 rheometer(COMPAC-100П, Sun Scientific Co., Tokyo, Japan)를 이용하여 10 회 반복 측정하였다. 측정은 distance $5 \mathrm{~mm}$, adaptor type circle, plunger $\phi 50 \mathrm{~mm}$ cylinder, table speed $120 \mathrm{~mm} / \mathrm{min}$, deformation ratio $90 \%$ 의 조건으로 하여 경도(hardness), 탄력성(springiness), 응집성(cohesiveness), 씹힘성(chewiness) 및 부착성(adhesiveness)의 값으로 나타 
내었다.

만두피의 관능적 평가

다시마 만두피의 관능검사는 훈련을 통해 선발한 관능요 원, 조리과학부 학생 20 명에게 각 특성치에 대해 설명한 후 7점 척도법으로 실시하였다. 즉 패널에게 1점에서 7점까 지 강도가 표시된 척도 위에 각 시료마다 정해진 특성의 강도를 표시하도록 하였으며, 관능검사는 오후 3 4시 사 이에 실시하였다. 모든 시료는 조리특성에서와 같은 방법 으로 조리한 후 $2 \times 2 \times 0.1 \mathrm{~cm}^{3}$ 로 잘라 흰색 폴리에틸렌 1 회용 접시에 담아 물과 함께 제공하였다. 평가 항목으로는 만두 피의 색, 향미, 입안에서의 느낌(쫄깃쫄깃한 정도, 치아에 달라붙는 정도), 맛 및 전체적인 기호도를 조사하였다.

\section{통계 분석}

자료의 통계처리는 SPSS(Statistics Package for the Social Science, 14.0, SPSS Inc., Chicago, IL, USA)를 이용하여 평균 및 표준편차를 구하고, 분산분석(ANOVA)과 Duncan 의 다중범위 시험법(Duncan's multiple range test)으로 통계 적 유의성 $(\mathrm{p}<0.05)$ 을 검증하였다.

\section{결과 및 고찰}

\section{아밀로그라프에 의한 점도 특성}

다시마 분말의 첨가량에 따른 아밀로그라프의 특성치는 Table 2 와 같다. 호화개시온도는 대조군의 경우 $65.1 \pm 1.1^{\circ} \mathrm{C}$ 를 나타냈으나, 다시마 분말의 첨가량이 증가될수록 $66.9 \pm 0.3^{\circ} \mathrm{C}, 68.5 \pm 0.1^{\circ} \mathrm{C}, 70.9 \pm 0.2^{\circ} \mathrm{C}, 71.5 \pm 0.5^{\circ} \mathrm{C}$ 로 대조군보 다 높은 온도에서 호화가 진행되었다. 이러한 결과는 대체 분을 증가시키면 단백질, 지방 등의 성분이 전분입자를 둘 러싸기 때문에 전분의 팽윤이 늦어진다는 연구와 관련성이 있는 것으로 판단된다 $(29,30)$. 최고점도는 대조군의 경우 $302 \pm 1.2$ B.U.로 나타났으나 다시마 분말 첨가량이 증가할 수록 276 $\pm 1.2,266 \pm 1.1,250 \pm 1.1$ 및 $236 \pm 1.0$ B.U.로 낮아졌 다. Pyun 등(21)은 볶은 콩가루를 첨가한 만두피의 특성에 서 콩가루를 볶는 과정에서 콩의 전분이 이미 호정화되어 존재하기 때문에 콩가루 첨가량이 증가할수록 최고점도가 낮아진다고 보고하여 본 결과와 비슷하였다. 또한 Park 등 (25)은 파래 분말을 $0,3,5,7$ 및 $9 \%$ 의 비율로 첨가하여 만두피를 제조했을 때 파래 분말의 첨가 비율이 증가할수록 최고 점도가 감소하였다고 보고한 바 있어 본 연구 결과와 비슷한 경향을 보였다. $95^{\circ} \mathrm{C}$ 에서 점도와 $95^{\circ} \mathrm{C}$ 에서 15 분간 유지한 후의 점도에서도 다시마 분말을 첨가한 양이 많아질 수록 감소하는 경향을 나타내었다. 밀가루의 점도에 영향 을 미치는 인자로는 단백질 함량, 입도 분포 등이 알려져 있으며(29), 본 연구에서 다시마 분말 첨가로 밀가루 글루텐
함량이 희석되고 전분양이 작아진 것 등이 점도 특성에 영향을 미친 것으로 추측된다.

Table 2. Effect of the sea tangle powder on the pasting properties of the dumpling shell

\begin{tabular}{ccccc}
\hline Sample & $\begin{array}{c}\text { Gelatinization } \\
\text { temperature } \\
\left({ }^{\circ} \mathrm{C}\right)\end{array}$ & $\begin{array}{c}\text { Viscosity at } \\
95^{\circ} \mathrm{C} \\
\text { (B.U.) }\end{array}$ & $\begin{array}{c}\text { Viscosity at } \\
95^{\circ} \mathrm{C} \text { after } 15 \\
\min \text { (B.U.) }\end{array}$ & $\begin{array}{c}\text { Maximum } \\
\text { viscosity } \\
\text { (B.U.) }\end{array}$ \\
\hline Control & $65.1 \pm 1.1^{\mathrm{d} 2)}$ & $305.1 \pm 2.0^{\mathrm{a}}$ & $260.1 \pm 1.5^{\mathrm{a}}$ & $302.1 \pm 1.2^{\mathrm{a}}$ \\
SP-1\% & $66.9 \pm 0.3^{\mathrm{c}}$ & $289.1 \pm 2.1^{\mathrm{b}}$ & $245.1 \pm 1.3^{\mathrm{b}}$ & $276.1 \pm 1.2^{\mathrm{b}}$ \\
SP-3\% & $68.5 \pm 0.1^{\mathrm{b}}$ & $275.2 \pm 1.1^{\mathrm{b}}$ & $235.2 \pm 1.2^{\mathrm{c}}$ & $266.2 \pm 1.1^{\mathrm{b}}$ \\
SP-5\% & $70.9 \pm 0.2^{\mathrm{ab}}$ & $260.1 \pm 1.2^{\mathrm{c}}$ & $227.2 \pm 1.1^{\mathrm{c}}$ & $250.1 \pm 1.1^{\mathrm{c}}$ \\
SP-7\% & $71.5 \pm 0.5^{\mathrm{a}}$ & $240.1 \pm 1.2^{\mathrm{d}}$ & $215.1 \pm 1.1^{\mathrm{d}}$ & $236.1 \pm 1.3$ \\
\hline
\end{tabular}

${ }^{1)}$ Control, no sea tangle powder, SP-1\%, $1 \%$ sea tangle powder added; SP-3\%, $3 \%$ sea tangle powder added; SP-5\%, 5\% sea tangle powder added; SP-7\%, 7\% sea tangle powder added.

${ }^{2)}$ Mean \pm standard deviation, values with different superscripts within columns are significantly different by Duncan's multiple range test at $p<0.05$.

\section{만두피의 조리특성}

다시마 분말의 첨가량을 달리하여 제조한 만두피의 조리 특성은 Table 3과 같다. 만두피의 조리 후 중량, 부피, 수분흡 수율은 대조군의 경우 $43.67 \pm 1.1 \mathrm{~g}, 26.55 \pm 1.1 \mathrm{~mL}$, $62.22 \pm 2.0 \%$ 였으며, 다시마 분말을 첨가한 군은 대조군에 비해 중량의 증가나 부피의 증가, 수분흡수율 등이 모두 유의적으로 높게 나타났으나, 첨가군 간의 유의차는 거의 없었다. Pyun 등(21)은 볶은 콩가루를 첨가한 만두피의 경 우 레시틴과 단백질의 보수성으로 인해 중량의 증가나 부피 의 증가, 수분흡수 등이 높게 나타났다고 보고하였는데, 본 연구에서도 다시마 분말에 존재하는 단백질의 보수성으 로 인한 결과로 추측된다. 조리중 고형분의 손실 정도를 나타내는 국물의 탁도는 다시마 분말 첨가군이 약간 증가하 여 용출 성분의 양이 조금 많은 것으로 나타났으나 다시마 분말 $7 \%$ 첨가 시료 외에는 유의적인 차이는 없었다. 울금 만두피(20), 새송이 만두피(26) 및 비파 만두피(27)의 연구

Table 3. Effect of the sea tangle powder on the cooking characteristics of the dumpling shell

\begin{tabular}{ccccc}
\hline Sample $^{1)}$ & $\begin{array}{c}\text { Weight } \\
(\mathrm{g})\end{array}$ & Volume (mL) & $\begin{array}{c}\text { Water absorption } \\
(\%)\end{array}$ & $\begin{array}{c}\text { Turbidity of } \\
\text { cooking water }\end{array}$ \\
\hline Control & $43.67 \pm 1.1^{\left.\mathrm{C}^{2}\right)}$ & $26.55 \pm 1.1^{\mathrm{b}}$ & $62.22 \pm 2.0^{\mathrm{c}}$ & $0.61 \pm 0 . .^{\mathrm{b}}$ \\
SP-1\% & $48.85 \pm 1.2^{\mathrm{b}}$ & $30.11 \pm 1.1^{\mathrm{a}}$ & $79.45 \pm 2.0^{\mathrm{b}}$ & $0.62 \pm 0.1^{\mathrm{b}}$ \\
SP-3\% & $50.26 \pm 1.2^{\mathrm{a}}$ & $33.68 \pm 1.2^{\mathrm{a}}$ & $83.52 \pm 2.1^{\mathrm{a}}$ & $0.62 \pm 0.1^{\mathrm{b}}$ \\
SP-5\% & $51.01 \pm 1.2^{\mathrm{a}}$ & $34.85 \pm 1.2^{\mathrm{a}}$ & $86.85 \pm 2.1^{\mathrm{a}}$ & $0.63 \pm 0.2^{\mathrm{b}}$ \\
SP-7\% & $51.05 \pm 1.3^{\mathrm{a}}$ & $35.71 \pm 1.3^{\mathrm{a}}$ & $87.21 \pm 2.2^{\mathrm{a}}$ & $0.69 \pm 0.3^{\mathrm{a}}$ \\
\hline
\end{tabular}

${ }^{11}$ Control, no sea tangle powder; SP-1\%, $1 \%$ sea tangle powder added; SP-3\%, 3\% sea tangle powder added; SP-5\%, 5\% sea tangle powder added; SP-7\%, 7\% sea tangle powder added.

${ }^{2}$ Mean \pm standard deviation, values with different superscripts within columns are significantly different by Duncan's multiple range test at $p<0.05$. 
에서는 대조군이 가장 적은 값을 보였고, 부재료 첨가가군 이 유의적으로 높게 나타났다고 보고하여 본 결과와 비슷하 였다.

\section{만두피의 색도}

다시마 분말의 첨가량을 달리하여 제조한 만두피의 색도 를 측정한 결과는 Table 4 와 같다. 명도(L값)은 대조군이 $73.57 \pm 0.2$ 로 가장 높았으며, $1,3,5$ 및 $7 \%$ 첨가 만두피의 경우 각각 $70.15 \pm 0.1,69.35 \pm 0.1,66.25 \pm 0.1$ 및 $62.55 \pm 0.1$ 로 다시마 분말 첨가량이 증가할수록 유의하게 낮아져 색이 어두워지는 경향을 보였으나 $1 \%$ 와 $3 \%$ 첨가 만두피는 유의 적인 차이는 없었다. $\mathrm{Kim}$ 등(31)은 쌀 압출팽화물의 색도는 원료의 색깔이 가장 큰 영향을 미치는데, 쌀 보다는 다시마 가 $\mathrm{L}$ 값이 낮아 다시마가루의 첨가량이 증가할수록 어두운 색을 나타낸다고 보고하였다. 다시마 머핀(17)의 경우 색도 는 다시마가루 첨가량이 증가할수록 $\mathrm{L}$ 값이 감소하였다고 보고하여 본 결과와 비슷하였다. 적색도(a)는 대조군에 비 해 다시마 분말 첨가군이 유의적으로 증가하여 $7 \%$ 첨가군 이 $-1.15 \pm 1.2$ 로 가장 높게 나타났다. Kang 등(26)의 새송이 버섯 만두피 특성에서 새송이 분말의 첨가량이 증가할수록 만두피의 $\mathrm{L}$ 값(명도)은 감소하였고, 적색도(a값)는 증가하 였음을 보고하여 본 결과와 같은 경향을 보였다. 황색도(b) 는 대조군에서 가장 높았고, 다시마 분말의 첨가량이 증가 할수록 유의적으로 감소하였다. $\operatorname{Kim}$ 등(17)은다시마 머핀 의 황색도를 나타내는 $\mathrm{b}$ 값은 다시마가루 첨가량이 증가할 수록 감소하였다고 보고하여 본 결과와 일치하였다. 다시 마 만두피의 색차는 다시마 분말 첨가에 의한 단백질 함량 의 증가로 glutamic acid이 풍부해져서 다시마 분말의 첨가 량이 증가될 수록 명도(L값)는 낮아지고, 또한 다시마 자체 에 함유된 카로틴류, 크산토필류, 엽록소, 후코키산친 등의 여러 가지 색소의 작용으로 적색도(a값)는 증가되지만, 황 색도(b값)는 감소되는 것으로 사료된다. 따라서 본 실험의 결과, 다시마 분말을 첨가한 만두피는 첨가량이 증가할수

Table 4. Effect of the sea tangle powder on the color of the dumpling shell

\begin{tabular}{cccc}
\hline \multirow{2}{*}{ Sample $^{1)}$} & \multicolumn{3}{c}{ Color values } \\
\cline { 2 - 4 } & $\mathrm{L}$ & $\mathrm{a}$ & $\mathrm{b}$ \\
\hline Control & $73.57 \pm 0.21^{\mathrm{a} 2)}$ & $-2.02 \pm 1.0^{\mathrm{d}}$ & $24.13 \pm 0.1^{\mathrm{d}}$ \\
SP-1\% & $70.15 \pm 0.1^{\mathrm{b}}$ & $-1.66 \pm 1.0^{\text {cd }}$ & $22.75 \pm 0.3^{\mathrm{c}}$ \\
SP-3\% & $69.35 \pm 0.1^{\mathrm{b}}$ & $-1.39 \pm 1.1^{\mathrm{c}}$ & $21.15 \pm 1.1^{\mathrm{c}}$ \\
SP-5\% & $66.25 \pm 0.1^{\mathrm{c}}$ & $-1.25 \pm 1.1^{\mathrm{b}}$ & $19.25 \pm 2.2^{\mathrm{b}}$ \\
SP-7\% & $62.55 \pm 0.1^{\mathrm{d}}$ & $-1.15 \pm 1.2^{\mathrm{a}}$ & $17.98 \pm 2.2^{\mathrm{a}}$ \\
\hline
\end{tabular}

${ }^{1)}$ Control, no sea tangle powder; SP-1\%, $1 \%$ sea tangle powder added; SP-3\%, 3\% sea tangle powder added; SP-5\%, 5\% sea tangle powder added; SP-7\%, 7\% sea tangle powder added.

${ }^{2}$ Mean \pm standard deviation, values with different superscripts within columns are significantly different by Duncan's multiple range test at $\mathrm{p}<0.05$.
록 명도(L값)와 황색도(b값)는 감소하였고, 적색도(a값)는 증가하는 경향으로 나타났다.

\section{만두피의 조직감}

다시마 분말의 첨가량을 달리하여 제조한 만두피의 조직 감 특성은 Table 5에 나타낸 바와 같이 경도, 탄력성, 응집성, 씹힘성 및 부착성을 rheometer로 측정하였다. 경도는 대조 군이 $0.77 \mathrm{~kg} / \mathrm{cm}^{2}$ 로 나타났고, 다시마 분말 첨가량이 많아질 수록 $0.99 \sim 1.71 \mathrm{~kg} / \mathrm{cm}^{2}$ 로 유의적으로 증가하는 경향을 보 였다 $(\mathrm{p}<0.05)$. 비파잎 분말을 첨가한 만두피(27)의 경우 첨 가량이 증가할수록 만두피의 경도가 증가하였다고 보고하 여 본 결과와 비슷하였다. $\operatorname{Kang}$ 과 $\operatorname{Kim}(32)$ 은 성분배합에 따른 만두피의 물성 변화에서 첨가량이 적거나 많이 함유되 었을 때는 만두피의 경도가 감소함을 보였다고 보고한 바 있어 본 실험의 결과와는 상이하였는데 이는 첨가물의 종류 에 따른 차이라고 추측된다. 만두피의 응집성, 씹힘성 및 부착성은 대조군에서 가장 낮았고, 다시마 분말 첨가량이 증가할수록 점차 증가하였다. Park 등(25)은 파래 분말을 첨가한 만두피 연구에서 파래 분말의 첨가량이 증가할수록 경도, 탄력성 및 씹힘성은 증가하였으나. 부착성과 응집성 은 감소하였다고 보고한 바 있다. Cho와 $\mathrm{Kim}$ (33)은 파래 분말을 첨가한 어묵의 경우 파래 분말의 첨가량이 증가할수 록 경도, 응집성 및 탄력성은 증가하였고 껌성과 파쇄성은 감소되었다고 보고하였다. Kang 등(26)은 새송이 분말을 첨가할 경우, 만두피의 부착성이 높다고 보고하였으며, $\operatorname{Park}(27)$ 도 비파잎 분말을 첨가한 만두피에서 첨가량이 증 가할수록 부착성은 증가하였다고 보고한 바 있어 본 결과와 일치하였다. 고아미 가루를 첨가한 만두피의 부착성은 고 아미 가루 첨가군이 유의적으로 낮았다고 보고된 바 있어서 (28) 상반된 결과를 보였는데, 이는 부재료의 고유한 특성에 기인한 결과로 생각된다. 탄력성은 대조군이 가장 높았고, 다시마 분말 첨가군이 대조군에 비해 감소하는 경향을 보였 으며, 이는 $\operatorname{Park}(27)$ 의 비파잎 분말을 첨가한 만두피 및

Table 5. Effect of the sea tangle powder on the textural properties of the dumpling shell

\begin{tabular}{cccccc}
\hline Sample $^{1)}$ & $\begin{array}{c}\text { Hardness } \\
\left(\mathrm{kg} / \mathrm{cm}^{2}\right)\end{array}$ & $\begin{array}{c}\text { Springiness } \\
(\%)\end{array}$ & $\begin{array}{c}\text { Cohesiveness } \\
(\%)\end{array}$ & $\begin{array}{c}\text { Chewiness } \\
(\mathrm{g})\end{array}$ & $\begin{array}{c}\text { Adhesiveness } \\
(\mathrm{g})\end{array}$ \\
\hline Control & $0.77 \pm 0.2^{\mathrm{d})}$ & $110.26 \pm 1.2^{\mathrm{a}}$ & $64.15 \pm 0.1^{\mathrm{b}}$ & $145.31 \pm 1.1^{\mathrm{c}}$ & $5.92 \pm 0.1^{\mathrm{d}}$ \\
SP-1\% & $0.99 \pm 0.1^{\mathrm{d}}$ & $104.10 \pm 1.1^{\mathrm{b}}$ & $66.54 \pm 0.2^{\mathrm{a}}$ & $152.22 \pm 1.2^{\mathrm{bc}}$ & $7.12 \pm 0.1^{\mathrm{cd}}$ \\
SP-3\% & $1.18 \pm 0.2^{\mathrm{c}}$ & $101.53 \pm 1.1^{\mathrm{b}}$ & $68.13 \pm 1.0^{\mathrm{a}}$ & $156.91 \pm 2.0^{\mathrm{b}}$ & $7.91 \pm 0.2^{\mathrm{c}}$ \\
SP-5\% & $1.37 \pm 0.1^{\mathrm{b}}$ & $95.12 \pm 0.1^{\mathrm{c}}$ & $68.77 \pm 1.0^{\mathrm{a}}$ & $159.80 \pm 2.1^{\mathrm{b}}$ & $8.75 \pm 1.0^{\mathrm{b}}$ \\
SP-7\% & $1.71 \pm 0.2^{\mathrm{a}}$ & $87.10 \pm 0.1^{\mathrm{d}}$ & $69.02 \pm 1.0^{\mathrm{a}}$ & $161.23 \pm 2.1^{\mathrm{a}}$ & $10.17 \pm 1.1^{\mathrm{a}}$ \\
\hline
\end{tabular}

${ }^{1)}$ Control, no sea tangle powder; SP- $1 \%, 1 \%$ sea tangle powder added; SP-3\%, 3\% sea tangle powder added; SP-5\%, 5\% sea tangle powder added; SP-7\%, 7\% sea tangle powder added.

${ }^{2)}$ Mean \pm standard deviation, values with different superscripts within columns are significantly different by Duncan's multiple range test at $\mathrm{p}<0.05$. 
$\operatorname{Kim}$ 과 Lee(28)의 고아미 분말 첨가 만두피에 관한 연구결 과와 유사하였다. 본 연구 결과, 다시마 분말을 첨가하였을 때 경도, 응집성, 씹힘성 및 부착성은 증가하였고 탄력성은 감소하였는데 이는 사용되는 부재료의 고유한 특성에 기인 한 결과로 생각된다.

만두피의 관능적 특성

다시마 분말 첨가량에 따른 만두피를 제조하여 조리한 만두피의 관능적 특성에 대한 결과는 Table 6과 같다. 만두 피의 색은 대조군의 경우 $5.10 \pm 1.02$, 다시마 분말 $1 \%$ 7\% 첨가군은 $5.20 \pm 1.0 \sim 5.55 \pm 1.1$ 로 대조군이 가장 낮았고, 다 시마 분말 $3 \%$ 첨가 만두피, $5 \%$ 첨가 만두피 순으로 높았다. 최근 들어 기능성 원료들을 사용하여 제조된 유색 식품에 대한 소비자의 선호도가 높아지면서 전통적인 흰색에 대한 고정관념이 컬러 푸드에 대한 관심 증가와 일반화로 점점 약해지고 있음을 알 수 있었다. 만두피의 향미 특성은 다시 마 분말 $1,3 \%$ 의 경우에는 시료 간 차이를 보이지 않았으나, $7 \%$ 첨가군은 대조군보다 더 낮게 평가되었다.

조직감 특성에서 쫄깃한 정도는 다시마 분말 첨가군이 더 좋은 점수를 받았으나 $7 \%$ 첨가군은 대조군보다 더 낮았 다. 만두피의 맛은 다시마 분말 첨가량이 많아질수록 증가 되었으나, $7 \%$ 첨가군에서는 낮은 점수를 보여 맛이 저하되 는 것으로 나타났다. 전체적인 기호도는 다시마 분말 $3 \%$ 첨가군이 가장 높게 나타나 다시마 분말을 일정량 첨가할 때 색채감 및 관능적 특성이 향상되는 것으로 평가되었다. 한편, rheometer를 이용한 기계적 조직감 측정 시, 다시마 분말의 첨가량이 증가될 수록 다시마 만두피의 씹힘성 및 부착성은 증가하였는데, 관능검사 결과에서는 맛이나 향미 의 경우 다시마 분말의 첨가량에 비례하지 않고 오히려 첨가량이 높은 $5 \%$ 와 $7 \%$ 보다는 $3 \%$ 첨가군에서 선호도가 가장 높게 나타났다. 이러한 결과는 Park 등(34)의 강황 분말을 첨가한 만두피에서 관능적 특성을 조사한 결과, 부 착성은 $3 \%$ 첨가군이 가장 높게 나타나 $5 \%$ 와 $7 \%$ 첨가군과 유의적인 차이를 보였고, 향미에서도 $5 \%$ 와 $7 \%$ 첨가군보다

Table 6. Effect of the sea tangle powder on the sensory evaluation score of the dumpling shell

\begin{tabular}{cccccc}
\hline Sample $^{1)}$ & Color & Flavor & Texture & Taste & $\begin{array}{c}\text { Overall } \\
\text { acceptability }\end{array}$ \\
\hline Control & $5.10 \pm 1.0^{\mathrm{d} 2)}$ & $3.23 \pm 0.0^{\mathrm{c}}$ & $5.21 \pm 1.0^{\mathrm{b}}$ & $3.91 \pm 0.0^{\mathrm{c}}$ & $5.16 \pm 1.0^{\mathrm{d}}$ \\
SP-1\% & $5.20 \pm 1.0^{\mathrm{c}}$ & $3.66 \pm 0.0^{\mathrm{a}}$ & $5.25 \pm 1.1^{\mathrm{b}}$ & $4.10 \pm 0.2^{\mathrm{b}}$ & $5.28 \pm 1.1^{\mathrm{b}}$ \\
SP-3\% & $5.55 \pm 1.1^{\mathrm{a}}$ & $3.60 \pm 0.0^{\mathrm{a}}$ & $5.49 \pm 1.0^{\mathrm{a}}$ & $4.42 \pm 0.4^{\mathrm{a}}$ & $5.57 \pm 1.1^{\mathrm{a}}$ \\
SP-5\% & $5.45 \pm 1.0^{\mathrm{b}}$ & $3.48 \pm 0.1^{\mathrm{b}}$ & $5.42 \pm 1.0^{\mathrm{a}}$ & $4.37 \pm 0.3^{\mathrm{a}}$ & $5.45 \pm 1.1^{\mathrm{ab}}$ \\
SP-7\% & $5.32 \pm 0.0^{\mathrm{bc}}$ & $3.15 \pm 0.1^{\mathrm{d}}$ & $5.15 \pm 1.1^{\mathrm{c}}$ & $4.11 \pm 0.2^{\mathrm{b}}$ & $5.21 \pm 1.1^{\mathrm{c}}$ \\
\hline
\end{tabular}

${ }^{1)}$ Control, no sea tangle powder; SP-1\%, $1 \%$ sea tangle powder added; SP- $3 \%, 3 \%$ sea tangle powder added; SP-5\%, 5\% sea tangle powder added; SP-7\%, 7\% sea tangle powder added.

${ }^{2)}$ Mean \pm standard deviation, values with different superscripts within columns are significantly different by Duncan's multiple range test at $p<0.05$.
는 3\% 첨가군에서 선호도가 더 높게 나타난 것과 유사하였다.

\section{요 약}

다시마의 활용성 증대 및 다양한 만두피 가공제품의 개 발을 위해 다시마 분말을 $1 \%, 3 \%, 5 \%$ 및 $7 \%$ 로 수준으로 첨가하여 제조한 만두피의 품질특성 결과는 다음과 같다. 호화개시온도는 다시마 분말의 첨가량이 증가될수록 점진 적으로 증가하는 경향을 보였다. 최고점도, $95^{\circ} \mathrm{C}$ 에서 점도 및 $95^{\circ} \mathrm{C}$ 에서 15 분간 유지한 후의 점도는 다시마 분말의 첨가량이 증가함에 따라 낮아지는 것으로 나타났다. 만두 피의 색도는 다시마 분말 첨가량이 증가함에 따라 명도 $(\mathrm{L}$ 값)와 황색도(b값)는 유의하게 감소하였으며, 적색도(a값) 는 각 시료간에 유의적으로 증가되었다. 다시마 분말을 첨 가한 만두피의 조리특성을 살펴보면, 대조군에 비해 첨가 군이 중량, 부피, 수분흡수율 등이 모두 높게 나타났다. 만두 피의 조직감은 다시마 분말 첨가량이 증가될수록 경도, 응 집성, 씹힘성 및 부착성은 높아졌으며, 탄력성은 감소하였 다. 만두피의 관능검사 결과, 색깔은 다시마 분말 $3 \%$ 와 $5 \%$ 첨가군이 기호도가 높게 나타났으며, 만두피의 향미 특성은 $1 \%$ 와 $3 \%$ 첨가군이 높게 나타났다. 만두피의 조직감 은 다시마 분말 $3 \%$ 와 $5 \%$ 첨가군이 높게 나타났으며, 만두 피의 맛은 다시마 분말 $3 \%$ 첨가군이 가장 좋은 것으로 평가되었다. 전체적인 기호도는 다시마 분말 $3 \%$ 첨가군이 가장 높게 나타나 다시마 분말을 일정량 첨가 시 관능적 특성이 향상되는 것으로 평가되었다. 이상의 결과로 볼 때 다시마 분말 특유의 색과 맛을 가미한 다시마 만두피를 제조할 경우 다시마 분말을 $3 \%$ 첨가하는 것이 만두피의 색채감 향상, 맛의 증진 및 전반적인 기호도면에서 가장 적절한 것으로 판단된다.

\section{References}

1. Cho HS, Park BH, Kim KH, Kim HA (2006) Antioxidative effect and quality characteristics of cookies made with sea tangle powder. Korean J Food Culture, 21, 252-257

2. Choi JH, Choi JS, Byun DS, Yang DS (1986) Basic studies on the development of diet for the treatment of obesity. Bull Korean Fish Soc, 19, 485-492

3. Kim SH, Park HY, Park WK (1988) Determination and physical properties of dietary fiber in seaweed products. J Korean Soc Food Nutr, 17, 320-325

4. Lee JH, Sung NJ (1980) The content of minerals in algae. J Korean Soc Food Nutr, 9, 51-58 
5. Bae TJ, Kang DS (2000) Processing of powdered seasoning material from sea tangle. Korean J Food Nutr, 13, 521-528

6. Han KH, Choi MS, Ahn CK, Yoon MJ, Song TH (2002) Soboru bread enriched with dietary fibers extracted from kombu. Korean J Food Cookery Sci, 18, 619-624

7. Kwon EA, Chang MJ, Kim SH (2003) Quality characteristics of bread containing laminaria powder. J Korean Soc Food Sci Nutr, 32, 406-412

8. Haroun-Bouhedja F, Ellouali M, Sinquin C, Boisson-Vidal C (2000) Relationship between sulfate groups and biological activities of fucans. Thromb Res, 100, 453-459

9. Bae TJ, Choi OS (1998) Changes of free amino acid compositions and sensory properties in Kochujang added sea tangle powder during fermentation. Korean J Food Nutr, 11, 556-560

10. Bang BH, Seo JS (2002) Characteristics of salt adsorption by calcium alginate beads. Korean J Food Nutr, 15, 89-96

11. Park BH, Cho HS, Kim KH, Kim SS, Kim HA (2008) The oxidative stability of solvent extracts of sea tangle powder (STP) and Maejakgwa made with STP. Korean J Food Cookery Sci, 24, 452-459

12. Ha JO, Park KY (2000) Na-binding capacity of alginate and development of sea tangle added kimchi. J Korean Soc Food Sci Nutr, 29, 95-100

13. Jeong EJ, Bang BH (2003) The effect on the quality of yogurt added water extracted from sea tangle. Koran J Food Nutr, 16, 66-71

14. Kim SJ, Moon JS, Park JW, Park IB, Kim JM, Rhim JW, Jung ST, Kang SG (2004) Quality of soybean paste (Doenjang) prepared with sweet tangle, sea mustard and anchovy powder. J Korean Food Sci Nutr, 33, 875-879

15. Cho YJ, Bang MA (2004) Effect of dietary sea tangle on blood glucose, lipid and glutathione enzyme in streptozptocin-induced diabetic rats. Korean J Food Culture, 19, 417-428

16. Cho MS, Hong JS (2006) Quality characteristics of Sulgidduk by the addition of sea tangle. Korean J Food Culture, 22, 37-44

17. Kim JH, Kim JH, Yoo SS (2008) Impacts of the proportion of sea-tangle on quality characteristics of muffin. Korean J Food Cookery Sci, 24, 565-572

18. Ham SS, Kim SH, Yoo SJ, Oh HT, Choi HJ, Chung MJ (2008) Biological activities of soybean sauce (Kanjang) supplemented with deep sea water and sae tangle. Koran J Food Preserv, 15, 274-279
19. Pyo SJ, Lee SM, Joo NM (2010) Optimization of germinated brown rice cookie prepared with (Laminaria longissima) sea tangle powder. Korean J Food Cookery Sci, 26, 617-626

20. Seo JS. (2013) Quality characteristics of a dumpling shell with Curcuma longa L. powder added. Korean J Food Preserv, 20, 621-627

21. Pyun JW, Nam HW, Woo IA (2001) A study on the characteristics of mandu-pi differing in roasted soy flour content. Korean J Food Nutr, 14, 287-292

22. Lee IO (2003) Quality characteristics of Mandupi with rice meal. MS Thesis, Chonnam National University, Korea, p 15-17

23. Cho HS, Kim KH (2008) Quality characteristics of mandupi with skate (Raja kenojei) flour. Korean J Food Culture, 23, 252-257

24. Kim KH, Park BH, Cho YJ, Kim SR, Cho HS (2009) Quality characteristics of shrimp flour added dumpling shell. Korean J Food Culture, 24, 206-211

25. Park BH, Ju SM, Cho HS (2010) Effect of Enteromorpha intenstinalis powder addition in the quality of dumpling shell. Korean J Food Preserv, 17, 814-819

26. Kang BH, Shin EJ, Lee SH, Lee DS, Hur SS, Kim SH, Son SM, Lee JM (2011) Quality characteristics of dumpling shell containing Pleurotus eryngii powder. J Korean Soc Food Sci Nutr, 40, 570-574

27. Park ID (2012) Quality characteristics of dumpling shell containing loquat leaf powder. J East Asian Soc Dietary Life, 22, 795-801

28. Kim HA, Lee KH (2013) The quality characteristics of mandupi added with goami powder. J East Asian Soc Dietary Life, 23, 98-106

29. Choe HD, Seo HM, Kim SL, Park YG, Lee CH (2003) Effect of $\beta$-glucan on gelatinization of barley starch. Korean J Food Sci Technol, 35, 545-550

30. Kim ML (2006) Antioxidative activity of extracts from Gardenia jasminoides and quality characteristics of noodle added Gardenia jasminoides powder. Korean J Food Cookery Sci, 22, 237-243

31. Kim EH, Kook SW, Jung ST, Park YK (2005) Properties of rice extrudates added with the sea tangle powder. Korean J Food Preserv, 12, 241-246

32. Kang KS, Kim BS (2003) Changes of rheology on the dumpling shell by added materials. Korean J Food Preserv, 10, 498-505

33. Cho HS, Kim KS (2014) Quality properties of fish paste containing green laver powder. Korean J Food Culture, 
29, 421-427

34. Park BH, An SA, Cho HS (2014) Quality characteristics of Mandupi added with Curcuma aromatica powder.

Korean J Food Culture, 29, 348-354 